\title{
Baby Spa Effect on Growth
}

\author{
Karningsih Sudiro*, Sri Mulyati \\ Midwifery Department, Health Polytechnic Ministry of Health Jakarta III \\ Jl. Arteri JORR Jatiwarna, Pondok Melati \\ Bekasi Selatan, INDONESIA \\ Corresponding author's email: mulyati.atmaja [AT] yahoo.com
}

\begin{abstract}
The aim of the study was to determine the effectiveness of Baby Spa on the growth of body weight and body length in infants aged 3-12 months. This research is a quasi-experimental study with a pretest-posttest design with control group design. The number of respondents as many as 70 respondents consisting of 1 group (35 respondents) with Baby Spa treatment and 1 group (35 respondents) was a control group without treatment. Data analysis using the MANCOVA test. The results of the study are Baby Spa effective for the growth of body weight and body length in infants aged 3-12 months. The conclusion that Baby Spa can be used to stimulate the growth of a baby's body weight and body length, but needs to pay attention to balanced feeding factors. The use of Baby Spa needs coordination between midwives and other health workers. Midwives must also provide health education about Baby Spa to stimulate baby growth so that babies can grow optimally.
\end{abstract}

Keywords - Spa baby, massage, Weight and Body length

\section{INTRODUCTION}

The percentage of short children under five in Indonesia is high, namely $37.2 \%$ according to the results of Riskesdas 2013, which tends to increase compared to the results of Riskesdas 2007 and 2010. Riau Islands Province with the lowest percentage of children under five and NTT with the highest percentage. The 2013 Basic Health Research noted that national stunting prevalence reached 37.2 per cent, increasing from 2010 (35.6\%) and 2007 (36.8\%). That is, the maximum growth is suffered by around 8 million Indonesian children or one in three Indonesian children. The incidence of stunting in Indonesia is higher than in other countries Southeast Asia, such as Myanmar (35\%), Vietnam (23\%), and Thailand (16\%), is very worried about the future of Indonesian children [1].

Data from the Ministry of Health of the Republic of Indonesia, (2016) shows the highest percentage of child growth disorders in the form of stunting in 2013 was in the province of East Nusa Tenggara (51.7\%), while the lowest percentage was Riau Islands (26.3\%), while DKI Jakarta reached the figure $27.5 \%$. This is very worrying because DKI Jakarta is the capital of the State of Indonesia which has access to health services that are very easy but has the highest percentage compared to the Riau Islands. Stunting is a problem of chronic malnutrition caused by insufficient nutrition in a long time due to feeding that is not in accordance with nutritional needs. In addition, it is also necessary to monitor the growth of infants and toddlers in health services or posyandu regularly, this is a very strategic effort to detect early growth disturbances. So that it needs to be given interventions in addition to nutritional needs, stimulation is also needed to help the child's growth [2].

The survey conducted by Pantai Indah Kapuk Hospital (2008) by means of multistage random sampling in a village in North Jakarta got $25.5 \%$ of children experiencing growth retardation. The lack of stimulation given to infants adds to the delay in the growth and development of the baby. A lot of research shows babies need early stimulation in various parts of the body and sensory tools to help the baby adjust to his new environment [3].

Stimulation of growth and development is very important for baby's growth and development. Considering the number of children under five in Indonesia is very large, which is about $10 \%$ of the entire population, then as a prospective generation of the nation, the quality of baby growth and development in Indonesia needs to get serious attention that is getting good nutrition, adequate stimulation and affordable by quality health services. In addition to hereditary and nutritional factors, factors that can optimize infant growth and development are early stimulation of growth and development that is carried out intensively in the first year of life. Stimulation can be done in various ways, one of which is with a baby spa [4]. 
A baby spa is a stimulation that is beneficial for baby's health and development. Babies who do baby spas will look fresh, healthy, vibrant and their growth and development are faster than babies who never do a baby spa at all [5]. Playing water, the baby's muscles will develop very well, the joints grow optimally, growth in body weight and body length will increase, and the body will become flexible. Swimming in the water will make all parts of the baby's body be trained because all the limbs are moved from the feet, hands to the head, although not perfect. The ability to control the baby's muscles will increase because when swimming in the water the gravitational effect is so low that it allows the baby to move more and all muscles can work optimally [5].

Baby spas are baby body treatments that can be done by bathing or bathing. Bathing and swimming will stimulate the baby's motor movements. Movement in the water will make all the baby's body members be trained, besides the ability to control the baby's muscles will increase. Baby spas will be effective, if done every two times a week and will not be effective if done routinely ie less than twice a week [5].

The results of research conducted by the Griffith for Educational Research Institute [6], of 7,000 babies in Australia, New Zealand and the United States proved that babies who learn to swim at an early age have many skills and reach a point of growth that is faster than those who do not swim [7]. Babies who do a baby spa every two times a week regularly at the age of 0-6 months will experience an increase every week 140-200 grams. Body weight is born twice at the end of the first 6 months and at the age of 6-12 months will experience an increase every week 85-400 grams. Body weight is three times the birth weight at the end of the first year [7]. This study aims to determine the effectiveness of Baby Spa on the growth of body weight and body length at $3-12$ months.

\section{METHODS}

A The type of research used is the Quasi-Experiment research. The design of this study is the Pre and Post Test with Control Group Design. In this study divided into 2 groups. The intervention group II is a group of babies who received baby spa treatment as much as $1 \mathrm{x} /$ week 4 times. The control group only visits again without being given a baby spa treatment. The study was carried out from May to November 2017 The population and sample in this study were all babies in the East Jakarta Practicum Mandiri (BPM) midwife. The sample size of 70 respondents divided into one intervention group consisting of 35 respondents and control group 35 respondents. Inclusion criteria that must be owned by respondents are Babies aged 3-12 months, healthy physical condition before the baby spa is performed, and the history of gestational age when the baby is born a term. Exclusion criteria are babies who do not regularly do baby spas.

\section{RESULTS}

Characteristics of Respondents Against Growth of Body Weight and Length in Infants Aged 3-12 Months. Other characteristics and factors that are confounding factors in baby spa effectiveness research on weight gain (BB) and body length (PB) consist of gender, birth weight, birth length, exclusive breastfeeding, the balance of infant feeding, disease history infection and immunization status. These variables have a measuring scale that varies starting from nominal, ordinal and ratio.

Birth weight (BBL), birth length (PBL), BB and PB categorization in infants in both groups were tested for normality using Kolmogorov Smirnov Test, BBL and PBL had the same p-value of $0.2(\alpha)$. $>0.05)$ this proves that the characteristics in both groups are homogeneous. The results of the normality test for the dependent variable BB before and after treatment have the same p-value which is $0.2(\alpha>0.05)$. Normality test data for PB before treatment has a pvalue of 0.52 and $\mathrm{PB}$ after 0.79 treatment, this proves that the two dependent variables include normal data. 
Table 1. Characteristics of Respondents in Control Groups and Intervention Groups Against Growth of BB and PB in Infants Age 3 - 12 Months in BPM East Jakarta Region 2017

\begin{tabular}{|c|c|c|c|c|}
\hline \multirow{2}{*}{ Variabel } & \multicolumn{2}{|l|}{ Control } & \multicolumn{2}{|c|}{ Intervention } \\
\hline & Frekuensi & $\%$ & Frekuensi & $\%$ \\
\hline \multicolumn{5}{|l|}{ Sex : } \\
\hline Female & 17 & 48,6 & 20 & 57,1 \\
\hline Male & 18 & 51,4 & 15 & 42,9 \\
\hline \multicolumn{5}{|l|}{ Birth Weight : } \\
\hline$\geq$ mean & 17 & 48,57 & 13 & 37,14 \\
\hline$<$ mean & 18 & 51,43 & 22 & 62,86 \\
\hline \multicolumn{5}{|l|}{ Birth length : } \\
\hline$\geq$ mean & 17 & 48,57 & 14 & 40 \\
\hline$<$ mean & 18 & 51,43 & 21 & 60 \\
\hline \multicolumn{5}{|c|}{ Exclusive breastfeeding : } \\
\hline breastfeeding & 32 & 91,4 & 34 & 97,1 \\
\hline No breastfeeding & 3 & 8,6 & 1 & 2,9 \\
\hline \multicolumn{5}{|c|}{ Nutritional balance : } \\
\hline Balance & 21 & 60 & 33 & 94,3 \\
\hline No balance & 14 & 40 & 2 & 5,7 \\
\hline \multicolumn{5}{|c|}{ Infectious Disease History: } \\
\hline None & 27 & 77,1 & 24 & 68,6 \\
\hline There is a history & 8 & 22,9 & 11 & 31,4 \\
\hline \multicolumn{5}{|c|}{ Immunization Status : } \\
\hline Complete & 31 & 88,6 & 26 & 74,3 \\
\hline No Complete & 4 & 11,4 & 9 & 25,7 \\
\hline
\end{tabular}

The results of table 1. show that there is a balance of respondents female and male. For birth weight in the control group and body length of birth in the control group which has a score> mean of $48.57 \%$ while that <of the mean is $51.43 \%$. Measures of birth weight and body length were born and in the intervention group each had a score > mean of $37.14 \%$ and $40 \%$. The table also shows that all respondents received exclusive breastfeeding more than $90 \%$. The variables of disease history in each of the two groups of respondents had a history of disease of more than $22.9 \%$ and $31.4 \%$ so that both groups of respondents had had an infection such as flue. While in the immunization status both control and intervention groups have incomplete immunization status, with $11.4 \%$ and $25.7 \%$ respectively.

Growth of body weight and length of baby's body aged 3-12 months before and after treatment in control and intervention groups

Table 2.Growth of Infant Weight and Body length Aged 3 - 12 Months Before and After Treatment in Control Groups and Intervention Groups in BPM East Jakarta Region 2017

\begin{tabular}{lllllll}
\hline \multicolumn{1}{c}{ Control } & Post & $\begin{array}{l}\boldsymbol{p} \text { - } \\
\text { value }\end{array}$ & Pre & Post & $\begin{array}{l}\boldsymbol{p} \text { - } \\
\text { value }\end{array}$ \\
\hline Variabel & Pre & & 0,000 & $6294 \pm 958,22$ & $7213 \pm 958,43$ & 0,000 \\
\hline Weight & $6886 \pm 1147,57$ & $7305 \pm 1092,98$ & 0,000 & 0,000 \\
\hline $\begin{array}{l}\text { Birth } \\
\text { length }\end{array}$ & $65,43 \pm 5,617$ & $67,83 \pm 5,491$ & 0,000 & $60,06 \pm 3.955$ & $63,43 \pm 3,845$ & \\
\hline
\end{tabular}

Based on table 2. shows that the mean size of body weight before and after treatment in the control group has increased from 6886 grams to 7305 grams, with each SD value 1147,573 and 1092,981. This was also shown in the intervention group which experienced an increase in body weight growth from 6294.29 grams to 7212.86 grams with SD 958,228 and 958,426 .

The results of the analysis of table 2. also give an illustration of the increase in length in the control group from 65.43 to 67.83 with each SD value of 5.617 and 5.491. The intervention group also experienced an increase in the size of the mean body length from 60.06 to 63.43 with SD values of 3.955 and 3.845 .

This analysis was carried out using dependent $t$ test to determine differences in results before and after the control group and the intervention group. The analysis was then carried out by using independent t tests to determine the differences in the results before and after the control group and the intervention group who were treated by the baby spa. 
Table 3.Differences in Growth of BB and PB Babies Aged 3 - 12 Months After Treatment in Control Groups and Intervention Groups in BPM East Jakarta Region 2017.

\begin{tabular}{lllllll}
\hline & Control & & \multicolumn{2}{c}{ Intervention } \\
\hline Variabel & Mean \pm SD & $\mathbf{9 5 \%}$ CI & $\begin{array}{l}\boldsymbol{p} \text { - } \\
\text { value }\end{array}$ & Mean \pm SD & $\mathbf{9 5 \%}$ CI & $\begin{array}{l}\boldsymbol{p} \text { - } \\
\text { value }\end{array}$ \\
\hline Weight & $7305 \pm 325,5$ & $531,2-307,6$ & 0,000 & $7212 \pm 221$ & $995,4-842,7$ & 0,000 \\
\hline $\begin{array}{l}\text { Birth } \\
\text { length }\end{array}$ & $67,83 \pm 1,09$ & $2,78-2,03$ & 0,000 & $63,43 \pm 0,69$ & $3,61-3,14$ & 0,000 \\
\end{tabular}

Bivariate analysis in table 3. Capable of both the control group and each group having a rise in BB. The increase in PB levels between groups and groups also has a different amount from the average. The control group which had mean diff mean of 2.4 and intervention group 3.371, while the group that received the baby spa service had a higher average increase with the control group.

When viewed from the p-value results, each group has a p-value of 0.000 so that both the control group that did not receive baby spa treatment and the intervention group had an influence on the increase in BB and PB in infants aged 3-12 months.

Growth of baby's body weight and body length after being given a baby spa treatment as much as $1 \mathrm{x}$ every week in a row as much as $4 \mathrm{x}$ in an orderly manner in the intervention group, then repeated measurements were proven to have experienced a very significant increase.

To analyze the effectiveness of baby spas on the growth of baby's body weight and body length, besides that it will also prove the confounding factors that contribute to the increase in BB and PB infants aged 3-12 months.

Table 4. Results of Multivariate Analysis of the Influence of Baby Spa and Confounding Factors on the Growth of Infant BB and PB Age 3 - 12 Months in BPM Jakarta Timur Region 2017 ( $\mathrm{n}=70)$

\begin{tabular}{llcccc}
\hline Source & $\begin{array}{l}\text { Dependent } \\
\text { Variable }\end{array}$ & df & Mean Square & F & p-value \\
\hline $\begin{array}{l}\text { Balance of giving baby } \\
\text { food }\end{array}$ & PB_post & 1 & 278.720 & 14.953 & 0.000 \\
& BB_post & 1 & 5495449.175 & 5.549 & 0.021 \\
Spa Baby & PB_post & 1 & 99.742 & 5.351 & 0.024 \\
& BB_post & 1 & 364233.910 & 0.368 & 0.546 \\
Corrected Total & PB_post & 69 & & & \\
& BB_post & 69 & & & \\
\hline
\end{tabular}

a. $\mathrm{R}$ Squared $=.331$ (Adjusted R Squared $=.311)$

b. R Squared $=.078$ (Adjusted R Squared $=.051$ )

Analysis from table 6 . found that there was a significant effect of baby spa on PB infant growth with p-value of 0.024 , while the confounding variable of infant feeding balance also influenced the growth of PB infants with p-value of 0,000 .

For the growth of BB babies, baby spa treatment does not have a significant effect because the results of multivariate analysis show p-value of 0.546 , while the balance of infant feeding has a significant effect with p-value of 0.021 .

The results of the mutivariate data analysis showed the value of Adjusted R Squared $=0.311$, which means that the baby spa and the balance of infant feeding can have an effect of 33\% on the growth of PB infants aged 3-12 months.

\section{DISCUSSION}

Baby spas improve baby sleep patterns and quality. Sleep will cause $75 \%$ of growth hormone to be released during sleep. This growth hormone is responsible for stimulating the growth of bones and tissues, this stimulates the growth of the baby's body length significantly [8]. This is consistent with the results of research that babies who get baby spa treatment have a very significant increase in body weight growth. The increase is due to the stimulation of all bones and tissues that make blood circulation smooth throughout the body so that it increases the growth of both the body's weight and body length.

Weight gain and body length in this study were also influenced by confounding factors such as the balance of feeding infants. This is in line with the opinion of Leonard, (2008) who found nutrition plays an important role in determining a child's growth. When experiencing growth, cells in the body need energy and other nutrients for growth, both body 
weight and body length [9].

This research is also in accordance with the results of research by Kurniawan, (2013) who suggested that by giving baby spa treatment for $1 \mathrm{x}$ in 1 week, the development and growth of the baby are more active. This happens because with the baby spa, in addition to providing a relaxing effect when swimming a baby will be trained in motor movements because the legs and body will move, help improve the digestive system and make it easy to eat, increase oxygen intake, develop lungs, stretch muscles, straighten the body structure and joints after birth so that the baby becomes healthy and comfortable and can grow optimally [10].

According to Galenia, (2014) the baby's body length experienced a rapid increase when compared to babies of the same age who were not carried out baby spa therapy. This is consistent with the results of the study in the intervention group who received baby spa treatment experienced a significant increase in body length compared to the control group who were not treated by the baby spa. This is proven by the mean diff value of 3,371 in the intervention group which is greater than the mean diff 2,4 value in the control case [11].

Research results from the World Aquatic Babies \& Children Network, (2016) which proves that a significant increase in growth occurs in infants who have followed the baby spa, the result is to increase the baby's appetite effect so that it has a very good increase in body weight, and body length when compared to babies of the same age who no baby spa therapy. These results are not in accordance with this study which proves the baby spa treatment only has a significant impact on increasing the baby's body weight aged 3-12 months. In addition to baby spas, there is a balance factor for baby feeding that can also contribute to an increase in body length and weight [12].

The baby spa treatment that was given to the intervention group in this study, was carried out every once a week in an orderly manner for a month, according to the results of the study by Lee, (2007) which revealed the results of his research that to increase infant growth the baby spa treatment should be done every one once a week (one month routine or regular). Differences in respondents in this study, babies who received baby spa treatment are aged 0-6 months will experience an increase every week 140-200 grams. Whereas in this study respondents who were treated with spa bays were 3-12 months old. The results of multivariate data analysis showed that the baby spa treatment was not significant in increasing BB but meaningful in increasing body length. This can occur because this study did not divide the age classification, so increasing weight gain and body length did not pay attention to age factors[13].

This study proves that the baby spa and baby feeding balance have an effect of $33 \%$ on the baby's body length growth between 3 - 12 months. This is also consistent with Kurniawan's research, (2013) which proves that $80 \%$ of 41 babies who are treated by a baby spa experience significant body length increases and are included in the normal infant growth category based on the growth chart of the baby.

Weight gain is not affected by baby spas but is influenced by the balance of infant feeding. According to Henningham and McGregor. (2008) that good nutrition is needed to ensure optimal infant growth and development. Nutritional needs both in quantity and quality are needed to maintain normal body function. This can happen because indeed for weight growth other than stimulation, good nutrition is needed for the baby, adjusted for age. If the baby is 0 - 6 months old then good nutrition is breast milk (ASI), known as exclusive breastfeeding, while the nutritional needs of infants> 6 months of age need additional food in addition to breastfeeding (MP-ASI) in the form of foods containing carbohydrates, protein and fat as an energy source [14]..

The results of multivariate analysis in this study prove that in addition to the baby spa which has an effect of $33 \%$ on the growth of body length and 67\% it is likely that other factors that must be considered that need to be investigated further, in accordance with the theory of Lesiapeto, et., Al. (2010) and the results of this study that nutritional balance also needs to be considered for this growth [15].

Baby spa service activities are one of the activities that can support the implementation of early stimulation, detection and intervention programs for child development at the primary health care level. This is in accordance with the government program to overcome stunting [16]. This is in accordance with the place of this research that uses the Mandiri Practical Midwife (BPM) which is the level of basic health services. So that baby spa activities can be developed gradually by midwives. In addition, baby spa services at the level of basic health services are easily accessible to the public.

\section{CONCLUSIONS}

The difference in body weight and body length growth where the intervention group who received baby spa treatment had a greater mean BB increase compared to the control group. Likewise, the intervention group that gets baby spa treatment has a greater PB mean compared to the control group.

The results of a multivariate analysis in this study prove that in addition to the baby spa which has an effect of $33 \%$ on the growth of body length, it is necessary to note other factors such as the balance of infant feeding. This is necessary so that the normal growth of body weight and body length does not rule out these two factors. Baby 
spas are needed for the growth of the baby but also need to provide a balanced meal for the baby and $67 \%$ are possibly other factors that must be considered that need to be further investigated, in accordance with the theory and results of previous research.

Need good coordination and cooperation between families and health workers especially midwives in using to provide baby spa services to stimulate the growth of baby's body weight and body length so that it is easily accessible to people who have babies. Policies on baby spa stimulation methods at the level of basic health services are easily accessible and applied to all health facilities that are useful for stimulating babies, especially for BPM service facilities.

\section{REFERENCES}

[1]. Kementerian Kesehatan RI. Profil Kesehatan Indonesia. Jakarta: Kementerian Kesehatan RI. 2016.

[2]. Kementerian Kesehatan RI. Pedoman Pemantauan Pertumbuhan Dan Perkembangan Anak. Jakarta: Kementerian Kesehatan RI. 2014.

[3]. Kurniawan, A. Hubungan Frekuensi Kunjungan Solus Per Aqua (SPA) Bayi kaitannya dengan Kenaikan Berat Badan Bayi Umur 0-6 bulan di Puskesmas Gantiwarno Klaten. Jurnal Terpadu Ilmu Kesehatan, Volume 2, Nomor 2,pdf. 2013.

[4]. Kanjilal et., al., Nutrition Status of Children in India: Household Socio Economic Condition as The Contextual Determinant. International Journal for Equality in Health. Biomed Central Ltd.2010.

[5]. Qoriesa, S. Hubungan Frekuensi Baby SPA dengan perkembangan bayi pada usia 4-6 bulan di Klinik Baby SPA Ananda Kecamatan Ambarawa Kabupaten Semarang. 2014.

[6]. Institut Griffith for Educational Research. Intervention swim for baby in Australia. Australia. 2007.

[7]. Roesli. ASI Panduan Praktis Ibu Menyusui. Banyu Media : Yogyakarta. 2009.

[8]. Rizema, S. Tips Sehat dengan Pola Tidur Tepat dan Cerdas. Buku Biru : Yogyakarta. 2011.

[9]. Leonard J. Exploring neonatal touch. The Wesleyan Journal of Psychology. 2008;3:39-27. 2008.

[10]. Kurniawan, A. Hubungan Frekuensi Kunjungan Solus Per Aqua (SPA) Bayi kaitannya dengan Kenaikan Berat Badan Bayi Umur 0-6 bulan di Puskesmas Gantiwarno Klaten . [Diakses tanggal 4 Juni 2015]. Di dapat dari :Jurnal Terpadu Ilmu Kesehatan, Volume 2, Nomor 2,pdf. 2013.

[11]. Galenia. Home Baby SPA.Jakarta : Penebar Swadaya. 2014.

[12]. World Aquatic Babies \& Children Network. Guidelines on Operation of Aquatic Programsfor Children Under Three Years of Age. Diunduh dari http://www.wabcswim.com /A08 Guidelines ForPrograms.htm. Tanggal 19 Desember 2016 Pukul 20.00 WIB. 2016.

[13]. Lee HK. The effects of infant massage on weight, height, and mother-infant interaction. Journal of Korean Academy of Nursing. 2007.

[14]. Henningham and McGregor. Public Health Nutrion. Jakarta : EGC. 2008.

[15]. Lesiapeto, et., al. Risk Factors of Poor Anthropometric Status in Children Under Five Years of Age Living in Rural Districts of The Eastern Cape and Kwazulu - natal Provinces South Africa. S Afr J Clin Nutr. 2010.

[16]. Dias JA, Manoel Ede J, Dias RB, Okazaki VH. Pilot study on infant swimming classes and early motor development. Percept Mot Skills. 2013. 